\title{
PERTANGGUNGJAWABAN PIDANA KORPORASI DI BIDANG LINGKUNGAN HIDUP
}

\author{
Dalinama Telaumbanua \\ Staf Pengajar Sekolah Tinggi Ilmu Hukum Nias Selatan dan Advokat \\ Korespondensi: dalitelaumbanua@gmail.com
}

\begin{abstract}
Abstrak
Artikel ini mengangkat topic mengenai kasus lumpur lapindo yang ditinjau dari kacamata tanggung jawab pidana korporasi terkait hukum lingkungan. Topik ini menarik untuk dibahas untuk memberikan pemahaman mengenai tanggung jawab pidana korporasi akibat dari tindakan perusahaan (corporate actions). Perusahaan sebagai entitas hukum terdiri dari banyak pihak, diantaranya adalah pemilik dan direksi, sehingga penentuan mengenai pihak yang bertanggung jawab dalam kejahatan yang terkait lingkungan hidup menjadi kompleks. Namun demikian, situasi seperti inilah yang menjadikan issue pertanggungjawaban pidana korporasi atas tindakan korporasi yang berdampak pada lingkungan ], menjadi menarik untuk dilakukan. Terkait dengan kasus lumpur lapindo, Lapindo Brantas Inc harus bertanggungjawab secara pidana dan membayar ganti kerugian akibat aktivitas lumpur lapindo tersebut.
\end{abstract}

Kata-kata Kunci: Pidana Korporasi; Lingkungan Hidup; Tanggung Jawab Korporasi.

\begin{abstract}
This article discussed the Lapindo volcanic mud case viewed from the perspectives of corporate criminal liability related to environmental law. This topic is of particular interest in terms of providing a better understanding of corporate criminal liability as a result of the actions of the company (corporate actions). Being a legal entity made up of many parties, including the owners and directors, determining responsibility for environmental crimes in a corporation becomes more complex. However, such situation makes the issue of corporate criminal liability for corporate actions that affect the environment interesting to be discussed. With regard to the case of Lapindo mud incident, Lapindo Brantas Inc should be criminally liable and pay damages resulting from the Lapindo mud incident.
\end{abstract}

Key Words: Corporate Crime; Environment, Corporate Responsibility. 


\section{PENDAHULUAN}

Pengaturan tindak pidana lingkungan hidup dalam PerundangUndangan tidak lain karena timbulnya kerugian terhadap aspek lingkungan hidup. Pihak yang mengalami kerugian dari suatu tindak pidana itulah yang disebut dengan korban (victim) tindak pidana atau korban kejahatan yang tentunya membutuhkan perlindungan atas kerugian yang dialami atau diderita.

Tindak pidana dapat diidentifikasikan dengan timbulnya kerugian, yang kemudian mengakibatkan lahirnya pertanggungjawaban pidana. Pertanggungjawaban pidana merupakan bentuk perlindungan hukum terhadap korban tindak pidana atas kerugian yang dideritanya.

Contoh kasus yang diangkat dalam tulisan ini yaitu Lumpur Lapindo. Contoh kasus ini diangkat karena akibat yang ditimbulkan oleh Lapindo ini sangat besar, luas, rumit dan melibatkan banyak pihak. Dimana Banjir Lumpur Panas Sidoarjo adalah peristiwa menyemburnya lumpur panas di lokasi pengeboran Lapindo Brantas Inc. di Dusun Balongnongo Desa Renokenongo, Kecamatan Porong, Kabupaten Sidoarjo, Jawa Timur, sejak tanggal 29 Mei 2006. Semburan lumpur panas selama beberapa bulan ini menyebabkan tergenangnya kawasan permukiman, pertanian, dan perindustrian di tiga kecamatan di sekitarnya, serta memengaruhi aktivitas perekonomian di Jawa Timur. Lokasi semburan lumpur ini berada di Porong, yakni kecamatan di bagian selatan Kabupaten Sidoarjo, sekitar $12 \mathrm{~km}$ sebelah selatan kota Sidoarjo. Kecamatan ini berbatasan dengan Kecamatan Gempol (Kabupaten Pasuruan) di sebelah selatan. ${ }^{1}$

Lokasi pusat semburan hanya berjarak 150 meter dari sumur Banjar Panji-1 (BJP-1), yang merupakan sumur eksplorasi gas milik Lapindo Brantas Inc sebagai operator blok Brantas. Oleh karena itu, hingga saat ini, semburan lumpur panas tersebut diduga diakibatkan aktivitas pengeboran yang dilakukan Lapindo Brantas di sumur tersebut.

Pihak Lapindo Brantas sendiri punya dua teori soal asal semburan. Pertama, semburan lumpur berhubungan dengan kesalahan prosedur dalam kegiatan pengeboran. Kedua, semburan lumpur kebetulan terjadi bersamaan dengan pengeboran akibat sesuatu yang belum diketahui. Namun bahan tulisan lebih banyak yang condong kejadian itu adalah akibat pemboran. Lokasi semburan lumpur tersebut merupakan kawasan pemukiman dan di sekitarnya merupakan salah satu kawasan industri utama di Jawa Timur. Tak jauh dari lokasi semburan terdapat jalan tol Surabaya-Gempol, jalan raya SurabayaMalang dan Surabaya-PasuruanBanyuwangi (jalur pantura timur), serta jalur kereta api lintas timur SurabayaMalang dan Surabaya-Banyuwangi. ${ }^{2}$

<http://januardi10015.blogspot.com/2011/03/artikel-mengenai-banjir-lumpur-panas.html> Ibid. 
Ada yang berpendapat bahwa lumpur Lapindo meluap karena kegiatan PT Lapindo di dekat lokasi itu. Lapindo Brantas melakukan pengeboran sumur Banjar Panji-1 pada awal Maret 2006 dengan menggunakan perusahaan kontraktor pengeboran PT Medici Citra Nusantara. Kontrak itu diperoleh Medici atas nama Alton International Indonesia, Januari 2006, setelah menang tender pengeboran dari Lapindo senilai US\$ 24 juta. Kandungan lumpur tersebut mengandung kadar PAH (Chrysene dan Benz(a)anthracene) mencapai 2000 kali di atas ambang batas, bahkan ada yang lebih dari itu. ${ }^{3}$ Bahaya kandungan PAH tersebut telah mengancam keberadaan manusia dan lingkungan seperti:

1. Kulit merah, iritasi, melepuh, dan kanker kulit jika kontak langsung dengan kulit;

2. Kanker;

3. Permasalahan reproduksi;

4. Membahayakan organ tubuh seperti liver, paru-paru, dan kulit.

Dampak PAH dalam lumpur Lapindo bagi manusia dan lingkungan mungkin tidak akan terlihat dalam waktu dekat, melainkan nanti sekitar 5-10 tahun kedepan. Dan yang paling berbahaya adalah keberadaan PAH ini akan mengancam kehidupan anak cucu, khususnya bagi mereka yang tinggal di sekitar semburan lumpur Lapindo beserta ancaman terhadap kerusakan lingkungan. Namun sampai Mei 2009 atau tiga tahun dari kejadian awal ternyata belum terdapat adanya korban sakit atau meninggal akibat lumpur tersebut.

Permasalahan lumpur lapindo ini dikaitkan dengan Undang-Undang Nomor 32 Tahun 2009 tentang Perlindungan dan Pengelolaan Lingkungan Hidup (UU No. 32 Tahun 2009) dengan memakai berbagai teori yang dianggap relevan mengenai pertanggungjawaban korporasi baik secara pidana dan juga pmberian ganti rugi terhadap korban.

\section{PEMBAHASAN}

\section{Teori Pertanggungjawaban}

Ada beberapa teori yang berkaitan dengan pertanggungjawaban yaitu:

\section{Teori Utilitarian}

Teori dari Jeremy Bentham ini adalah individualis utilitarian. Menurut Bentham, apa yang cocok digunakan atau cocok untuk kepentingan individu adalah apa yang cenderung untuk memperbanyak kebahagiaan. Hukum sebagai tatanan hidup bersama harus diarahkan untuk menyokong raja suka dan serentak mengekang raja duka. Yang mesti diingat, kepercayaan Bentham adalah kepercayaan seorang individualis, bukan seorang sosialis. ${ }^{4}$

Teori Bentham ini mengudang kritik dari John Stuart Mill yang mengatakan bahwa terlalu naïf asumsi Bentham yang menganggap seolah tidak ada pertentangan antara kegunaan individu dan kegunaan umum. Peran John

Ibid.

Bernard L Tanya dkk, Teori Hukum (Genta Publishing 2010) 93. 
Stuart Mill dalam teori hukum terletak dalam penyelidikan-penyelidikannya mengenai hubungan-hubungan keadilan, kegunaan, kepentingankepentingan individu dan kepentingan umum. ${ }^{5}$

John Stuart Mill menekankan citacita tentang manusia. Ia menyatakan bahwa kodrat manusia dapat menjadi patokan kegiatan manusia agar mencapai kebahagiaan. Kodrat manusia ini merupakan ciri individualitas yang terkandung kebebasan dalam diri manusia. Kehendak tiap masing-masing individu apabila disatukan merupakan kehendak umum apabila dicapai bersama akan tercipta kebahagian umum yang memungkinkan tercapainya tujuan kehendak individu. Ini artinya bahwa kehendak umum harus dicapai secara kolektif dari setiap kehendak individu masing-masing. ${ }^{6}$

Pendapat John Stuart Mill ini memunculkan apa yang disebut dengan prinsip manfaat yakni setiap orang bebas mengembangkan potensi dirinya yang tidak mengganggu kehendak umum yang telah dicapai bersama. Pemaksaan menjadi wajib untuk menekankan kehendak individu yang melanggar kehendak umum. Dengan ini maka kehendak alami individu hilang demi mewujudkan kehendak umum. John Stuart Mill mengatakan bahwa jika kehendak umum tercapai maka kehendak individu akan tercapai pula.
Oleh karenanya kaum utilitarian mengatakan bahwa kebahagian individu harus terlebih dahulu mewujudkan kehendak umum.

\section{Strict liability}

Strict liability atau tanggung jawab mutlak adalah unsur kesalahan tidak perlu dibuktikan oleh pihak penggugat sebagai dasar pembayaran ganti rugi. Yang menjadi alasan mengapa Strict Liability yang diapakai yaitu karena sulitnya membuktikan adanya kesalahan pada delik-delik lingkungan hidup. Disamping itu juga mengingat korban dampak kejahatan di bidang kehutanan ini secara umum tidak hanya menguras sumber daya alam, akan tetapi juga modal manusia dan modal sosial yang sangat besar, bahkan modal kelembagaan yang berkelanjutan. ${ }^{7}$

\section{Vicarious Liability}

Vicarious liability adalah pertanggungjawaban pidana yang dibebankan kepada seseorang atas perbuatan orang lain. Pertanggungjawaban demikian misalnya terjadi dalam hal perbuatan yang dilakukan orang lain itu adalah dalam ruang lingkup pekerjaan atau jabatan. Dengan demikian dalam pengertian vicarious liability ini, walaupun seseorang tidak melakukan sendiri suatu tindak pidana dan tidak mempunyai kesalahan dalam arti yang biasa, ia masih dapat dipertanggungjawabkan. ${ }^{8}$

W. Friedmann, Teori dan Filsafat Hukum (PT RajaGrafindo Persada 1994) 120.

<http://arestoe2003.blogspot.com/2008/04/utilitarianisme.html> diakses 7 April 2014

Muladi dan Dwidja Priyatno, Pertanggungjawaban Pidana Korporasi (Kencana Prenada Media Group 2010) 110.

8 Ibid. 
Pertanggungjawaban Korporasi: Studi Kasus Lumpur Lapindo

Dalam membahas pertanggungjawaban pidana terhadap lingkungan hidup ini, penulis mengaitkan contoh kasus lumpur Lapindo di atas dengan Pasal 116 UU No.32 tahun 2009 tentang Perlindungan dan Pengelolaan Lingkungan Hidup. Dimana Apabila tindak pidana lingkungan hidup dilakukan oleh, untuk, atau atas nama badan usaha, tuntutan pidana dan sanksi pidana dijatuhkan kepada:

a. badan usaha; dan/atau

b. orang yang memberi perintah untuk melakukan tindak pidana tersebut atau orang yang bertindak sebagai pemimpin kegiatan dalam tindak pidana tersebut.

Apabila tindak pidana lingkungan hidup dilakukan oleh orang, yang berdasarkan hubungan kerja atau berdasarkan hubungan lain yang bertindak dalam lingkup kerja badan usaha, sanksi pidana dijatuhkan terhadap pemberi perintah atau pemimpin dalam tindak pidana tersebut tanpa memperhatikan tindak pidana tersebut dilakukan secara sendiri atau bersama-sama.

Selain itu, menurut Pasal 117 UU No. 32 tahun 2009 "Jika tuntutan pidana diajukan kepada pemberi perintah atau pemimpin tindak pidana, ancaman pidana yang dijatuhkan berupa pidana penjara dan denda diperberat dengan sepertiga." Kemudian dalam Pasal 118 "Terhadap tindak pidana Apabila tindak pidana lingkungan hidup dilakukan oleh, untuk, atau atas nama badan usaha, tuntutan pidana dan sanksi pidana dijatuhkan kepada badan usaha, sanksi pidana dijatuhkan kepada badan usaha yang diwakili oleh pengurus yang berwenang mewakili di dalam dan di luar pengadilan sesuai dengan peraturan perundang-undangan selaku pelaku fungsional."

Selain pidana tersebut di atas, terhadap badan usaha dapat dikenakan pidana tambahan atau tindakan tata tertib berupa:

a. perampasan keuntungan yang diperoleh dari tindak pidana;

b. penutupan seluruh atau sebagian tempat usaha dan/atau kegiatan;

c. perbaikan akibat tindak pidana;

d. pewajiban mengerjakan apa yang dilalaikan tanpa hak; dan/atau

e. penempatan perusahaan di bawah pengampuan paling lama 3 (tiga) tahun.

Pengaturan tindak pidana lingkungan hidup dalam PerundangUndangan tidak lain karena timbulnya kerugian terhadap aspek lingkungan hidup. Pihak yang mengalami kerugian dari suatu tindak pidana dalam hal ini korban (victim) tindak pidana atau korban kejahatan yang tentunya membutuhkan perlindungan atas kerugian yang dialami atau diderita.

Tindak pidana biasanya diidentifikasikan dengan timbulnya kerugian, akibat kerugian ini yang kemudian melahirkan pertanggungjawaban pidana. Pertanggungjawaban pidana merupakan bentuk perlindungan 
hukum terhadap korban tindak pidana atas kerugian yang dideritanya.

Pertanggungjawaban pidana yaitu menetapkan dan menempatkan pelaku tindak pidana sebagai subjek hukum pidana dalam ketentuan perundangundangan agar pelaku tindak pidana dapat dipertanggungjawabkan atas segala perbuatan yang dilakukannya sebagai perwujudan tanggung jawab karena kesalahannya terhadap orang lain yang dalam hal ini sebagai korban. Dapat dipertanggungjawabkannya subjek hukum pidana tersebut tentunya memberikan deterrent effect untuk tidak melakukan tindak pidana, sehingga dapat mencegah terjadinya tindak pidana dan secara langsung mencegah adanya korban tindak pidana.

Terkait korporasi sebagai pelaku tindak pidana lingkungan hidup tidak hanya sebagai penetapan dan penempatan korporasi sebagai subjek hukum pidana saja, tetapi perlu adanya ketentuan khusus tentang pertanggungjawaban untuk korporasi. Pertanggungjawaban pidana adalah pertanggungjawaban setiap orang terhadap tindak pidana yang dilakukannya. Dengan ini tentunya harus ada tindak pidana yang dilakukan baru dapat dipertanggungjawabkan terhadap setiap orang melakukan tindak pidana tersebut. Oleh karena itu, yang dipertanggungjawabkan setiap orang adalah tindak pidana yang dilakukannya. Akan tetapi tidak selalu setiap orang yang melakukan tindak pidana dapat dipidana, karena untuk memenuhi syarat agar dapat dipertanggungjawabkannya setiap orang atas tindak pidana yang dilakukannya harus adanya unsur kesalahan sebagai wujud rasa keadilan.

Dirasakan tidak adil apabila setiap orang dijatuhi pidana padahal sama sekali tidak bersalah. Adanya unsur kesalahan dari pertanggung-jawaban pidana inilah yang dalam hukum pidana dikenal sebagai asas kesalahan yakni asas tiada pidana tanpa kesalahan.

Pertanggungjawaban pidana setiap orang berdasarkan unsur kesalahan tersebut sebenarnya berkaitan dengan tindak pidana yang dilakukan oleh manusia alamiah sebagai subjek hukum pidana. Untuk pertanggungjawaban pidana berdasarkan unsur kesalahan terhadap korporasi bukan hal yang mudah, karena korporasi sebagai subjek hukum pidana tidak mempunyai sifat kejiwaan seperti halnya manusia alamiah. Sehubungan dengan pertanggungjawaban pidana berdasarkan kesalahan tersebut Barda Nawawi Arief berpendapat bahwa "dari berbagai perumusan tindak pidana lingkungan hidup di dalam perundangundangan lingkungan hamper selalu mencatumnkan unsur kesengajaan atau kealpaan atau kelalaian. Maka dapat dikatakan bahwa pertanggungjawaban pidana dalam perundang-undangan lingkungan mengandung prinsip system liability based on fault (pertanggungjawaban berdasarkan kesalahan). Jadi pada prinsipnya menganut asas kesalahan.

Hal ini seringkali menjadi kendala dalam lapangan pembuktian yakni tidak 
mudah membuktikan adanya kesalahan pada delik lingkungan dan kesalahan pada korporasi atau badan hukum. Kendala di atas apabila dihubungkan dengan pengaturan penyelesaian sengketa perdata lingkungan hidup saat ini, yakni Pasal 88 UU No.32 tahun 2009 sudah dimungkinkan adanya tanggung jawab mutlak "strict liability". Dimana setiap orang yang tindakannya, usahanya, dan/atau kegiatannya menimbulkan ancaman serius terhadap lingkungan hidup bertanggung jawab mutlak atas kerugian yang terjadi tanpa perlu pembuktian unsur kesalahan.

Yang dimaksud dengan "bertanggung jawab mutlak" atau strict liability adalah unsur kesalahan tidak perlu dibuktikan oleh pihak penggugat sebagai dasar pembayaran ganti rugi. Ketentuan ayat ini merupakan lex specialis dalam gugatan tentang perbuatan melanggar hukum pada umumnya. Besarnya nilai ganti rugi yang dapat dibebankan terhadap pencemar atau perusak lingkungan hidup menurut Pasal ini dapat ditetapkan sampai batas tertentu. Yang dimaksud dengan "sampai batas waktu tertentu" dalam hal ini adalah jika menurut penetapan peraturan perundangundangan ditentukan keharusan asuransi bagi usaha dan/ atau kegiatan yang bersangkutan atau telah tersedia dana lingkungan hidup.

Menurut Barda Nawawi Arief memandang bahwa strict liability merupakan pengecualian berlakunya asas tiada pidana tanpa kesalahan. Pada strict liability pembuatnya tetap diliputi kesalahan. Hal ini dimungkinkan dapat efektif apabila diterapkan terhadap sulitnya membuktikan adanya kesalahan pada delik-delik lingkungan hidup dan kesalahan pada korporasi atau badan hukum tersebut. Di samping itu, mengingat korban dampak kejahatan korporasi di bidang lingkungan hidup ini secara umum tidak hanya dapat menguras sumber daya alam, tetapi juga modal manusia dan modal sosial yang sangat besar, bahkan modal kelembagaan yang berkelanjutan.

Semburan lumpur ini membawa dampak yang luar biasa bagi masyarakat sekitar maupun bagi aktivitas perekonomian di Jawa Timur. Sampai Mei 2009, PT Lapindo, melalui PT Minarak Lapindo Jaya telah mengeluarkan uang baik untuk mengganti tanah masyarakat maupun membuat tanggul sebesar Rp. 6 Triliun.

Lumpur menggenangi 16 desa di tiga kecamatan. Semula hanya menggenangi empat desa dengan ketinggian sekitar 6 meter, yang membuat dievakuasinya warga setempat untuk diungsikan serta rusaknya areal pertanian. Luapan lumpur ini juga menggenangi sarana pendidikan dan Markas Koramil Porong. Hingga bulan Agustus 2006, luapan lumpur ini telah menggenangi sejumlah desa/kelurahan di Kecamatan Porong, Jabon, dan Tanggulangin, dengan total warga yang dievakuasi sebanyak lebih dari 8.200 jiwa dan tak 25.000 jiwa mengungsi. Karena tak kurang 10.426 unit rumah terendam lumpur dan 77 unit rumah ibadah terendam lumpur.

Lahan dan ternak yang tercatat terkena dampak lumpur hingga Agustus 
2006 antara lain: lahan tebu seluas 25,61 ha di Renokenongo, Jatirejo dan Kedungcangkring; lahan padi seluas 172,39 ha di Siring, Renokenongo, Jatirejo, Kedungbendo, Sentul, Besuki Jabon dan Pejarakan Jabon; serta 1.605 ekor unggas, 30 ekor kambing, 2 sapi dan 7 ekor kijang. Sekitar 30 pabrik yang tergenang terpaksa menghentikan aktivitas produksi dan merumahkan ribuan tenaga kerja. Tercatat 1.873 orang tenaga kerja yang terkena dampak lumpur ini.

Empat kantor pemerintah juga tak berfungsi dan para pegawai juga terancam tak bekerja. Tidak berfungsinya sarana pendidikan (SD, SMP), Markas Koramil Porong, serta rusaknya sarana dan prasarana infrastruktur (jaringan listrik dan telepon). Rumah/tempat tinggal yang rusak akibat diterjang lumpur dan rusak sebanyak 1.683 unit. Rinciannya: Tempat tinggal 1.810 (Siring 142, Jatirejo 480, Renokenongo 428, Kedungbendo 590, Besuki 170), sekolah 18 (7 sekolah negeri), kantor 2 (Kantor Koramil dan Kelurahan Jatirejo), pabrik 15, masjid dan musala 15 unit.

Kerusakan lingkungan terhadap wilayah yang tergenangi, termasuk areal persawahan. Tak kurang 600 hektar lahan terendam. Ditutupnya ruas jalan tol Surabaya-Gempol hingga waktu yang tidak ditentukan, dan mengakibatkan kemacetan di jalur-jalur alternatif, yaitu melalui Sidoarjo-Mojosari-Porong dan jalur Waru-tol-Porong. Penutupan ruas jalan tol ini juga menyebabkan terganggunya jalur transportasi Surabaya-Malang dan Surabaya-
Banyuwangi serta kota-kota lain di bagian timur pulau Jawa. Ini berakibat pula terhadap aktivitas produksi di kawasan Ngoro (Mojokerto) dan Pasuruan yang selama ini merupakan salah satu kawasan industri utama di Jawa Timur. Seluruh jaringan telepon dan listrik di empat desa serta satu jembatan di Jalan Raya Porong tak dapat difungsikan dan masih banyak lagi kerugian yang dialami korban akibat semburan lumpur Lapindo ini.

Dalam kasus ini, Polda Jawa Timur telah menetapkan 13 tersangka. Namun perkara pidana tersebut dihentikan oleh penyidik Polda Jawa Timur dengan alasan bahwa dalam perkara perdatanya gugatan YLBHI dan Walhi kepada Lapindo dan pemerintah telah gagal. Selain itu, adanya perbedaan pendapat para ahli. Gerakan Menutup Lumpur Lapindo pernah mengajukan namanama ahli tambahan, para ahli terkemuka Indonesia dan luar negeri yang tergabung dalam Engineer Drilling Club (EDC) yang mendukung fakta kesalahan pemboran berdasarkan hasil audit Badan Pemeriksa Keuangan tersebut, tetapi ditolak oleh penyidik Polda Jawa Timur (tidak ditanggapi).

Pemerintah dianggap tidak serius menangani kasus luapan lumpur panas ini. Masyarakat adalah korban yang paling dirugikan, di mana mereka harus mengungsi dan kehilangan mata pencaharian tanpa adanya kompensasi yang layak. Pemerintah hanya membebankan kepada Lapindo pembelian lahan bersertifikat dengan harga berlipat-lipat dari harga NJOP yang rata-rata harga tanah di bawah Rp. 
100 ribu- dibeli oleh Lapindo sebesar Rp 1 juta dan bangunan Rp 1,5 juta masing-masing permeter persegi. untuk 4 desa (Kedung Bendo, Renokenongo, Siring, dan Jatirejo) sementara desadesa lainnya ditanggung APBN, juga penanganan infrastruktur yang rusak.Hal ini dianggap wajar karena banyak media hanya menuliskan data yang tidak akurat tentang penyebab semburan lumpur ini.

Salah satu pihak yang paling mengecam penanganan bencana lumpur Lapindo adalah aktivis lingkungan hidup. Selain mengecam lambatnya pemerintah dalam menangani lumpur, mereka juga menganggap aneka solusi yang ditawarkan pemerintah dalam menangani lumpur akan melahirkan masalah baru, salah satunya adalah soal wacana bahwa lumpur akan dibuang ke laut karena tindakan tersebut justru berpotensi merusak lingkungan sekitar muara.

PT Lapindo Brantas Inc sendiri lebih sering mengingkari perjanjian-perjanjian yang telah disepakati bersama dengan korban.Menurut sebagian media, padahal kenyataannya dari 12.883 buah dokumen Mei 2009 hanya tinggal 400 buah dokumen yang belum dibayarkan karena status tanah yang belum jelas. Namun para warga korban banyak yang menerangkan kepada Komnas HAM dalam penyelidikannya bahwa para korban sudah diminta menandatangani kuitansi lunas oleh Minarak Lapindo Jaya, padahal pembayarannya diangsur belum lunas hingga sekarang. Dalam keterangannya kepada DPRD Sidoarjo pada Oktober 2010 ini Andi Darusalam
Tabusala mengakui bahwa dari sekitar 13.000 berkas baru sekitar 8.000 berkas yang diselesaikan kebanyakan dari korban yang berasal dari Perumtas Tanggulangin Sidoarjo. Hal ini menunjukkan bahwa banyak keterangan dan penjelasan yang masih simpang siur dan tidak jelas.

Tujuan dari kebijakan menetapkan suatu sanksi pidana yaitu dalam rangka perlindungan masyarakat untuk mencapai kesejahteraan. Salah satu bentuk perlindungan masyarakat tersebut adalah perlindungan hukum untuk tidak menjadi korban tindak pidana, ataupun perlindungan hukum apabila telah menjadi korban dari suatu tindak pidana.

Mengenai korban kejahatan, para pakar berpendapat sebagai berikut. Menurut Arif Gosita, korban kejahatan adalah mereka yang menderita fisik, mental, sosial sebgai akibat tindakan jahat mereka yang mau memenuhi kepentingan diri sendiri atau pihak yang menderita. Yang dimaksud dengan mereka adalah: (a) Korban orang per orangan atau korban individual; (b) Korban yang bukan orang per orangan, misalnya suatu badan, organisasi, lembaga. Para korban adalah impersonal, komersial, kolektif adalah keterlibatan umum, keserasian sosial dan pelaksanaan perintah. Misalnya, pada pelanggaran peraturan dan ketentuan-ketentuan Negara.

Menurut Muladi, korban adalah orang-orang yang baik secara individual maupun kolektif telah menderita kerugian, termasuk kerugian fisik atau 
mental, emosial, ekonomi, atau gangguan substansial terhadap hakhaknya yang fundamental, melalui perbuatan atau komisi yang melanggar hukum pidana di masing-masing negara termasuk penyalahgunaan kekuasaan. Sementara menurut Lilik Mulyadi, korban kejahatan dibedakan menjadi:

a. Ditinjau dari sifatnya, ada yang individual atau kolektif. Korban individual dapat diidentifikasi sehingga perlindungan korban dapat dilakukan secara nyata, tetapi korban kolektif lebih sulit di identifikasi. Walau demikian, dalam Pasal 91 UU No. 32 tahun 2009 diberikan jalan keluar, di mana masyarakat berhak mengajukan gugatan perwakilan kelompok untuk kepentingan dirinya sendiri dan/ atau untuk kepentingan masyarakat apabila mengalami kerugian akibat pencemaran dan/atau kerusakan lingkungan hidup. Gugatan dapat diajukan apabila terdapat kesamaan fakta atau peristiwa, dasar hukum, serta jenis tuntutan di antara wakil kelompok dan anggota kelompoknya. Ketentuan mengenai hak gugat masyarakat dilaksanakan sesuai dengan peraturan perundangundangan.

b. Ditinjau dari jenisnya, korban kejahatan ada yang bersifat langsung yaitu korban kejahatan itu sendiri dan tidak langsung (korban semu/abstrak) yaitu masyarakat. Sebagaimana kutipan Lilik Mulyadi dari Sellin dan Wolfgang, membagi jenis korban yaitu:
1) Primary Victimization, korban individual. Jadi korbannya orang per orangan, bukan kelompok.

2) Secondary Victimization, di mana yang menjadi korban adalah kelompok, seperti badan hukum.

3) Tertiary Victimization, yang menjadi korban adalah masyarakat luas.

4) Mutual Victimization, yang menjadi korban adalah si pelaku sendiri. Misalnya: pelacuran, perzinahan, narkotika.

5) No Victimization, bukan berarti tidak ada korban, melainkan korban tidak segera dapat diketahui, misalnya konsumen yang tertipu dalam menggunakan suatu hasil produksi.

c. Ditinjau dari kerugiannya, dapat diderita oleh seseorang, kelompok masyarakat maupun masyarakat luas. Selain itu, kerugian korban dapat bersifat materiil yang dapat dinilai dengan uang dan immaterial yaitu perasaan takut, sakit, sedih, kejutan psikis dan lain sebagainya.

Sementara C. Maya Indah mengemukakan bahwa defenisi korban meliputi pula defenisi direct victims of crime (korban tindak pidana yang secara langsung) dan indirect victims of crime (korban tindak pidana yang tidak langsung), baik secara individu maupun secara kolektif yang mengalami penderitaan, baik fisik, mental, maupun material, serta mencakup korban dari penyalahgunaan kekuasaan. ${ }^{9}$ 
Dalam hal pemberian ganti rugi ini, malahan dibebankan dalam APBN dimana Pemerintah menganggarkan pembelian tanah dan bangunan bagi desa yang terkena bencana lumpur Sidoarjo dapat keluar tahun ini. Dana tersebut sudah dicantumkan APBN-P tahun 2011. ${ }^{10}$ Dimana Sudah disepakati sembilan RT di tiga desa yang sebelumnya di APBN 2011 diberikan biaya kontrak, tunjangan hidup dan evakuasi. Maka sekarang diberikan pembiayaan, pembelian tanah, dan bangunan. Setiap hal yang terkait dengan pembiayaan atau pembayaran baik itu ganti rugi maupun evakuasi dan relokasi.

Mestinya pemberian ganti rugi akibat lumpur Lapindo ini menjadi tanggung jawab pihak Lapindo. Pihak Pemerintah mungkin bermaksud baik mengganti kerugian yang dialami, akan tetapi timbul persoalan lain karena APBN yang digunakan itu seharusnya bias digunakan untuk pembangunan lain yang mungkin lebih penting. Selain itu, dengan di anggarkannya penggantian kerugian akibat tindakan korporasi ini semakin memperjelas bahwa pertanggungjawaban terhadap tindakan korporasi sangat sulit dilakukan, karena pembuktian perbuatannya yang sangat sulit untuk dilakukan (siapa yang berbuat, siapa yang bertanggungjawab, dan lain sebagainya) dan juga masalah politik yang menggerogoti dan menghinggapi setiap kebijakan yang diambil oleh penguasa.

\section{PENUTUP}

Adapun kesimpulan dalam tulisan ini yakni Lumpur lapindo ini diakibatkan oleh pengeboran Lapindo Brantas Inc. oleh karena lumpur Lapindo meluap karena kegiatan PT Lapindo di dekat lokasi itu. Lumpur Lapindo mengakibatkan kerugian yang sangat besar dan kompleks yang dialami oleh masyarakat, badan usaha dan juga infrastruktur milik Negara dan juga bias menimbulkan cacat secara fisik sehingga dianggap sebagai kejahatan korporasi. Lapindo Brantas Inc harus bertanggungjawab secara pidana dan membayar ganti kerugian akibat aktivitas lumpur lapindo tersebut.

Pertanggungjawaban pidana korporasi ini sangat sulit dilakukan, oleh karena pembuktian perbuatannya yang sangat rumit untuk dilakukan dan juga masalah politik yang menggerogoti dan menghinggapi setiap kebijakan yang diambil.

\section{DAFTAR BACAAN}

\section{Buku}

Friedmann, W., Teori dan Filsafat Hukum (PT RajaGrafindo Persada Jakarta 1994).

Indah, Christina Maya, Perlindungan Korban Suatu Perspektif Victimologi dan Kriminologi (Widya Sari Press Salatiga 2010).

10 <http://economy.okezone.com/read/2011/07/27/20/484997/> diakses 7 April 2014. 
Muladi \& Dwidja Priyatno, Pertanggungjawaban Pidana Korporasi (Kencana Prenada Media Group Jakarta 2010).

Tanya, Bernard L, dkk, Teori Hukum (Genta Publishing Yogyakarta 2010).

\section{Internet}

<http://economy.okezone.com/read/ $2011 / 07 / 27 / 20 / 484997 />$ diakses 7 April 2014

<http://januardi10015.blogspot.com/ $2011 / 03 /$ artikel-mengenai-banjirlumpur-panas.html> diakses 7 April 2014.

<http://arestoe2003.blogspot.com/ 2008/04/utilitarianisme.html> diakses 7 April 2014. 